\title{
Vertebrate Mitochondrial Genome Organization: Evidence of Convergent Evolution
}

\author{
Maria Paula Montaña Lozano \\ Universidad del Tolima \\ Manuela Alejandra MorenoCarmona \\ Universidad del Tolima \\ Jesus Mauricio Ochoa Capera \\ Universidad del Tolima \\ Natalia Sofía Medina Camacho \\ Universidad del Tolima \\ Jeffrey L. Boore \\ Providence St. Joseph Health and Institute for Systems Biology \\ Carlos Fernando Prada Quiroga ( $\square$ cfpradaq@ut.edu.co) \\ Universidad del Tolima
}

\section{Research Article}

Keywords: Comparative genomics, Bioinformatics analyses, Mitochondrial genomes, Gene order

Posted Date: April 29th, 2021

DOI: https://doi.org/10.21203/rs.3.rs-456479/v1

License: (c) (i) This work is licensed under a Creative Commons Attribution 4.0 International License.

Read Full License 
2 Running head: Vertebrate Mitochondrial genome evolution

4 Maria Paula Montaña Lozano ${ }^{1}$, Manuela Alejandra Moreno Carmona ${ }^{1}$, Jesus Mauricio Ochoa 5 Capera $^{1}$, Natalia Sofía Medina Camacho ${ }^{1}$, Jeffrey L. Boore ${ }^{2}$ and Carlos Fernando Prada 6 Quiroga ${ }^{1, *}$

$8{ }^{1}$ Grupo de investigación de Biología y ecología de artrópodos. Facultad de Ciencias. $9 \quad$ Universidad del Tolima. Colombia.

$10{ }^{2}$ Providence St. Joseph Health and Institute for Systems Biology, 401 Terry Avenue N, 11 Seattle, WA 98109, USA.

$12 *$ *orrespondence: cfpradaq@ut.edu.co

\section{Abstract}

15 The evolution of the vertebrate mitochondrial genome has been the focus of numerous 16 genetic and evolutionary studies over the last several decades. Initially, sampling was heavily 17 biased toward taxonomic orders of greatest economic or health importance, but recent 18 advances in DNA sequencing technology have facilitated a much broader phylogenetic 19 sampling from which we can clarify general evolutionary trends such as patterns of gene 20 rearrangement. Toward this end, we performed a comparative genomic analysis of the 2,831 21 vertebrate mitochondrial genomes representing 12 classes that are available in the NCBI 
22 database. Using a combination of bioinformatics methods, we determined that there is a great

23 variation in the proportion of rearrangement by gene and by taxonomic class, with higher

24 rates being observed in Reptilia, Amphibia, Petromyzonti, Mammalia, and Actinopteri.

25 Further, within each class, there is large variation in proportion of reorganization among

26 different orders or even taxonomic families. Eleven events of convergence in the genic order

27 among different taxonomic orders were determined, most of them not previously reported.

29 Keywords

30 Comparative genomics, Bioinformatics analyses, Mitochondrial genomes, Gene order

\section{Introduction}

33 Vertebrate mitochondrial genomes (mtDNAs) are circular, typically 14-20 kbp, and contain

34 genes for 13 proteins (atp6, atp8, cob, coxl-3, nad1-6, nad4L), 2 ribosomal RNA (rRNAs;

$35 \quad r r n S, r r n L$ ), and 22 transfers RNA (tRNAs; $\operatorname{trnX}$, where $\mathrm{X}$ is the one letter code for the 36 corresponding amino acid ${ }^{1-3}$.

37 Gene rearrangement is one of the most studied features for animal mitochondrial genomes ${ }^{4}$.

38 In vertebrates, the order of genes on the mitochondrial genomes is generally considered to be

39 conserved ${ }^{5}$. However, it has been reported some rearrangement include gene transposition,

40 gene loss and gene duplication ${ }^{6}$. These events have often been modeled by a process of

41 tandem duplication followed by random gene losses (TDRL) which is the most frequently

42 invoked model to explain the diversity of gene rearrangements in metazoan mitogenomes ${ }^{6-}$

$43{ }^{8}$. Due to advances in DNA sequencing technology, it has become possible to compare 
44 hundreds of vertebrate mitochondrial genomes from various taxonomic lineages, showing 45 that gene order can vary far more than previously recognized ${ }^{2,9,10}$. Although the ancestral 46 vertebrate mitochondrial gene arrangement is mostly found in vertebrates ${ }^{2}$, some

47 rearrangements have long been noted among birds, some species of lizards, crocodilians, 48 marsupial mammals, snakes, tuatara, lamprey, amphibians, and some species of fish; most of 49 these rearrangements involve genes flanking one or both of the two origins of replication, 50 sites where gene duplications that have been proposed to mediate translocations may be 51 especially common ${ }^{2,8,10-14}$.

52 Differences in size in some vertebrate mitochondrial genomes are due to deletion or 53 duplication events, mainly in the D-loop region and/or tRNAs, and as an artifact in the 54 databases where genomes reported as complete are actually missing some portion, often parts 55 of the D-loop region ${ }^{3,12}$. Rearrangements of mitochondrial genes can have profound 56 functional implications on gene expression and genome replication, can be correlated with 57 genomic variation, aspects of physiology, molecular mechanism, life history, or genomic 58 evolutionary processes ${ }^{1,15}$.

59 The aim of this study is to systematically compare the rate of mitochondrial gene 60 rearrangements in each of the taxonomic orders of vertebrates and to identify possible 61 convergence events that occurred in the evolution of this important animal group.

62

63 Methods

64 Mitochondrial Genome Sequences of Vertebrate Species 
65 We retrieved the sequences and gene annotations of the 2,831 complete vertebrate

66 mitochondrial genomes, representing 143 taxonomic orders organized into 12 taxonomic

67 classes (Myxini, Petromyzonti, Elasmobranchii, Holocephali, Cladistii, Actinopteri,

68 Coelacanthi, Dipneusti, Amphibia, Reptilia, Aves, and Mammalia) that are available at the

69 organelle genome resources database from NCBI

70 (https://www.ncbi.nlm.nih.gov/genome/browse\#!/organelles/ ) as of December 20, 2019.

71 Mitogenomes representing strains within the same species were not included (as in the case

72 of the mouse, Mus muscullus, for which there are now mitogenome sequences for at least

7320 strains). A list of these species, sorted taxonomically, with the GenBank Reference IDs

74 and reported gene rearrangements is provided in the Supplementary Table S1.

Gene order and rearrangements rate analysis

77 We attempted to verify the correctness of reported gene annotations based on the

78 methodology previously used by Prada and Boore ${ }^{12}$. The ancestral gene order of the

79 vertebrate mitochondrial genome postulated by different authors ${ }^{1,2,16}$, was used to identify

80 the possible reorganizations (duplication, deletion and inversion-translocation) by

81 observational analysis of the genes and their annotations using the program Geneious

82 version $4.8 .5^{17}$. For this aim, a numerical gene order was made (from 1 to 37 , considering 1

83 as the $\operatorname{trnI}$ and 2 as $\operatorname{trn} Q$ gene; and so on) and their gene orientation according to the

84 position of the gene in the heavy (plus/plus as + ) and light strand (plus/minus as -). For this

85 analysis, the D-loop region was not taken into account due to the absence of its annotation

86 or, indeed, even of the sequence (complete or partial) likely to contain this feature, even

87 those listed as being complete, in a significant number of $\mathrm{mt}$ genomes. 
The NCBI-BLAST2 sequence comparison program

(https://blast.ncbi.nlm.nih.gov/Blast.cgi) and MUSCLE multiple sequence alignments were used to corroborate whether the annotations were correct or not. We compared each gene that was reported as being inverted relative to the putative ancestral arrangement with the orthologous genes of closely related species in each orientation with $80 \%$ sequence identity as the threshold for determining the correct orientation. The MITOS web server (http://mitos.bioinf.uni-leipzig.de/index.py) ${ }^{18}$ was used to corroborate the annotation, size and orientation of tRNAs and coding genes The tRNAscan-SE 2.0 program ${ }^{19}$ was used to detect tRNA-encoding genes and confirm their orientation in the mitochondrial genomes.

The gene rearrangements proportion of each Vertebrate class and/or order, by means of the following equation (1):

$$
\text { PRo: } \frac{N R o}{N E * 37} * 100
$$

PRo: Proportion of rearrangements for class and/or order; NRo: Number of rearrangements for orders; NE: Number of species of each order; 37: Total mitochondrial genome genes. The gene rearrangements proportion of each Vertebrate class for gene, by means of the following equation (2):

$$
P R g: \frac{N R g}{N E} * 100
$$

RRg: Proportion of rearrangements for gene; NRg: Number of rearrangements for gene; NE: Number of species of each order.

These results were compared with those obtained by the qMGR program ${ }^{4}$. The results generated by the analysis of gene rearrangements rate and those of qMGR of each 
Vertebrate order were graphed using the Heatmapper program (http://www.heatmapper.ca/)

20. A phylogeny was constructed from reference molecular phylogeny of the Vertebrate ${ }^{21}$; contrasting them with those presented in this study.

\section{Ancestral state estimation and phylogenetic analysis}

Several methodologies were used to estimate the ancestral status in the vertebrate mitochondrial genome. Common interval analysis was conducted using CREx ${ }^{18}$ for pairwise comparisons and TreeREx ${ }^{22}$ for inference of ancestral genome states. Paired CREx comparisons of the representative mitochondrial genome of some taxonomic classes or orders against the vertebrate ancestral mitochondrial genome were performed to determine the number of minimal genome rearrangement events separating each taxonomic order from the ancestral state. The CREx and TreeREx programs use the same set of rearrangement events: transpositions, inversions, reverse transpositions and TDRL, as well as the same algorithm called common interval, however, they cannot analyze gene duplications or deletions.

Mitochondrial genomes within each vertebrate taxonomic order were aligned using the MAUVE aligner software v.2.3. progressive alignment algorithm ${ }^{23}$. Alignments were made using the following parameters: skip-refinement and seed-weight $=15$, total alignment, determining local collinear blocks (LCB) and pairs of LCBs. The option of using seed families in the anchorage and linear genomes was ignored. the Mauve phylogenetic trees were used for the of TreeRex analysis. Phylogenetic trees were visualized and edited using FigTree ver $1.4^{24}$. 
131 We conducted a multiple genome rearrangement using GRIMM software

132 (http://grimm.ucsd.edu) which uses Hannenhalli's and Pevzner's (HP) algorithms ${ }^{25}$ for

133 computing uni-chromosomal and multi-chromosomal genomic distances ${ }^{26}$; to infer

134 convergent and parallelism evolution on the vertebrate mitochondrial genomes.

135

136 Results

137 Gene Annotation errors in the Vertebrate mitochondrial genome

138 There are a total of 104904 genes annotated in the 2831 vertebrate mitochondrial genomes

139 found in the NCBI database, including 178 gene duplications detected by the presence of an

140 identical copy of such gene. A total of 1951 cases are annotated to be in arrangements

141 differing from the ancestral vertebrate mitochondrial gene order (Supplementary Table S1).

142 Of all these reorganizations, 389 were identified as gene annotation errors, an error

143 percentage of $20 \%$. Of these, tRNAs have the highest level of annotations errors (94.6\%)

144 with the highest values in $\operatorname{trnE}(15.3 \%)$ and $\operatorname{trnP}(14.6 \%), 4.3 \%$ are errors in rRNA genes,

145 represented mostly by errors in $\operatorname{rrnS}(3 \%)$, and $1.1 \%$ of the annotation errors in coding

146 genes are only in the case of nad6 gene. Actinopteri, Reptilia, Aves, and Mammalia with

147 126, 89, 77, and 68 genes with annotation errors, respectively (Table 1).

149 Rearrangement level in the Vertebrate mitochondrial genome

150 In this study a total of 1562 reorganizations in the vertebrate mitochondrial genome were

151 confirmed. Our results show that 33.2\% (942 of 2,831) of the mitogenomes (present in 6 of

152 the 12 class) have at least one rearrangement (Table 1). The present work revealed that the 
species with the most rearrangements were in the classes Actinopteri (628), Reptilia (475)

154 and Amphibia (262), compared to other classes (Table 1). However, when calculating the

155 rearrangements rate by class, these vary from one to another; showing that the classes with

156 low rearrangement rate (>0 to 5\%) are Reptilia (4.85\%), Amphibia (3.27\%), Petromyzonti

157 (2.70\%), Mammalia (1.66\%), Actinopteri (1.24\%); and Aves (0.65\%). The only taxonomic

158 groups with vertebrate ancestral order were Myxini, Elasmobranchii, Holocephali,

159 Cladistii, Coelacanthi and Dipneusti (Table 1 and Fig. 1).

160 Within some taxonomic classes, there are orders wherein all sampled species retain the 161 ancestral order and others with gene rearrangements. For example, in the Actinopteri class,

16234 of the 59 taxonomic orders have all sampled species retaining the ancestral vertebrate

163 mitochondrial gene arrangement; the other orders have species with one or more

164 rearrangements. The order Saccopharyngiformes (belonging to Actinopteri class), has many

165 species $(72.8 \%)$ with rearranged mtDNAs in comparison with other orders of the same

166 class as Anguilliformes (5.1\%); observing gene rearrangements in only 4 analyzed

167 genomes. Within the Reptilia class, the Serpentes and Crocodilia orders have higher

168 proportion of reorganization (9.8\% and 8.1\%, respectively) compared to Amphisbaena

169 (4.0\%), Lacertilia (2.7\%) or Testudines (0.19\%). Anura order (belonging to the Amphibia

170 class), presents a major proportion of reorganization (4.8\%) in comparison with Caudata

$171(0.78 \%)$ or Gymnophiona (1.30\%) orders (Fig. 2, Supplementary Table S2).

172 On the other hand, our results show that the most frequent rearrangements in vertebrates are 173 inversions/translocations with $87.3 \%$ (1363/1562), followed by duplications with $11.4 \%$

174 (181/1562) and deletions with 1.3\% (21/1562). However, in some classes, certain events

175 predominate as in the case of Aves, where $94.4 \%(68 / 72)$ of the rearrangements are 
176 duplications and $5.6 \%$ (4/77) are deletions (There are no confirmed

177 inversions/translocations in this class.) In the case of Mammalia, only

178 inversions/translocations were confirmed (Table 1). In addition, of all rearrangements,

$17985.3 \%(1332 / 1562)$ are of the tRNA genes, mainly associated with

180 inversions/translocations (92\%) (Supplementary Table S1).

181 Our results show differences in quantifying mitochondrial genome rearrangement

182 proportion in each gene by taxonomic order between manual and qMGR analysis. For

183 example within the class Actinopteri, our analyses confirm that most or all of the genes

184 present a high proportion of gene rearrangements. In Batrachoidiformes rearrangements

185 were found in $100 \%$ of genes whilst in Saccopharyngiformes $72.8 \%$ of genes presented

186 rearrangements. In Saccopharyngiformes, manual analysis finds a proportion of gene

187 rearrangements of $72.8 \%$, while qMGR shows $37.8 \%$ (Fig. 2). In this sense, the most

188 rearrangements in vertebrate mitochondrial genome were observed mainly in tRNA genes,

189 concentrating in certain clusters such as $\operatorname{trnL}, n a d 1, \operatorname{trnI},-\operatorname{trn} Q, \operatorname{trn} M$; $\operatorname{trn} W$, - $\operatorname{trn} A$, - $\operatorname{trnN}$, -

$190 \operatorname{trnC}$ and $\operatorname{trnH}, \operatorname{trnS}, \operatorname{trnL}, n a d 5$, -nad6, -trnE, cob, trnT, -trnP (Figure 2). Of the 1562

191 genes with confirmed rearrangements, 103, 101, 145, 70, and 58 are present in the trnL,

$192 n a d 1, \operatorname{trnI}$, -trnQ, trnM region, respectively; while 55, 56, 56 and 60 are observed in $\operatorname{trn} W$,-

$193 \operatorname{trn} A,-\operatorname{trnN},-\operatorname{trn} C ; 38,44,108,30,70,80,50,81$ and 85 are in $\operatorname{trn} H, \operatorname{trn} S, \operatorname{trnL}$, nad5, -

194 nad6, -trnE, cob, trnT, -trnP. In contrast, it can be observed that within the vertebrate

195 mitogenome there are relatively conserved blocks, as is the case of $\operatorname{cox} 2, \operatorname{trnK}$, atp8, atp6,

$196 \operatorname{cox} 3, \operatorname{trn} G, \operatorname{nad} 3, \operatorname{trnR}, \operatorname{nad} 4 L, \operatorname{nad} 4(9,13,11,10,9,11,10,12,10$, and 12

197 rearrangements, respectively) (Fig. 2). However, it can be observed that each taxonomic

198 order in vertebrates, presents rearrangement proportions in different regions. For example, 
while in most taxonomic orders, the rearrangements are concentrated in adjacent genes of the control region, high rearrangements proportions in $\operatorname{trnI}$, $\operatorname{trn} Q$, $\operatorname{trn} M$ and adjacent genes are shown in Pleuronectiformes, Myctophiformes (Actinopteri class) and Serpentes;

Crocodilia in nad4, trnH, trnS, trnL. Also Marsupialia and mentioned taxonomic orders of Actinopteri class, share rearrangements proportions in $\operatorname{trn} W,-\operatorname{trn} A$, $-\operatorname{trnN}$, - $\operatorname{trn} C$ (Supplementary Table S2, Fig. 2).

On the other hand, of the 178 duplications present in vertebrate mitochondrial genome, are concentrated mainly in tRNA genes with the 83.7\% (149/178), observed in the nad6-trnEcob-trnT-trnP region $(19,23,22,29$, and 35 copies of each gene respectively) and of the trnM gene (35 copies of the single gene; a single copy per mitogenome). The taxonomic class with the highest number of duplicated genes is Aves with $38.2 \%$ (68/178) followed by amphibians with 30.9\% (55/178) of all gene duplications detected in vertebrates. Most of the duplications observed in amphibians occurred in trnM gene ( 23 copies), all observed in certain species of the order Anura. Another characteristic observed in Aves was the presence of duplicated pseudogenes (ineffective copies). In this taxonomic group, 42 of these copies were observed, most of them (21) correspond to pseudogenes of cob; mainly observed in the order Pelecaniformes. In this same taxonomic order, it was also observed copies in the form of pseudogenes of $n a d 6, \operatorname{trn} E$, $\operatorname{trn} T$ and $\operatorname{trn} P$ genes $(6,2,7$, and 5, respectively). Although it is common to find a single additional copy (duplicate) of one or two genes, in certain genomes more than two presumably effective copies of the same gene are observed; in the case of Cnemaspis limi (Reptilia, Squamata) that contains four copies of the trnA gene. Similarly, tandem duplications of complete mitochondrial regions are observed, as in the case of Aeluroscalabotes felinus (Reptilia, Squamata) with 53 genes in 
222

223

224

225

226

227

228

229

230

231

232

233

234

235

236

237

238

239

240

241

242

243

total (18974 bp) and in Breviceps adspersus (Amphibia, Anura) with 51 genes (28757 bp)

(Supplementary Table S1). Of the 21 deletions that we founded, they also are concentrated in the tRNA genes (19/21), mainly in trnT-trnP region with 3 and 6 deletions, respectively. The most frequent taxonomic group of deletions is Actinopteri with 9 deletions, mainly in the $\operatorname{trn} P$ gene with 5 deletions (Supplementary Table S1).

\section{Gene Arrangement Convergence in the vertebrate mitochondrial genome}

Our results indicate that within the 1020 reorganized mitogenomes (with respect to the order of the ancestral genes of vertebrate), 138 different genetic architectures were identified; 11 of these are grouped in convergences in the genetic order observed in 764 species (Table 2). The remaining 127 are unique genetic arrangements in vertebrates, as in the case of Phrynocephalus przewalskii (Reptilia, Squamata), with duplications of the trnF and -trnP genes, and inversions/translocations in $\operatorname{trn} Q$ and in the second copy of -trnP gene (Supplementary Table S1).

Our results indicate that there are taxonomic groups with many different architectures. For example, all the sampled species within Aves share a reorganization from the vertebrate ancestral order, but relatively conserved within this taxonomic class. Only 29 species of the 620 analyzed have any type of rearrangement with respect to the Aves ancestral order (see CREX analysis). Among Saccopharyngiformes (Actinopteri), there are three different architectures in the four analyzed species, while in other taxonomic groups they are more conserved; for example, within the class Mammalia, all marsupials (29 mt genomes) share a single rearrangement from the vertebrate ancestral order (Table 1). 
244 In the convergences (11) four of them (8-11) are between orders belonging to the same

245 taxonomic class of fish, in addition, 10 and 11 are convergences in deletion and duplication

246 events of a gene, respectively. All cases of convergence between different taxonomic orders

247 are represented in Fig. 3.

249 Analysis of gene order with CREX and TreeREx

250 CREX analysis was done with the purpose of determining a putative ancestral gene order

251 for the taxonomic orders that presented more rearrangements, here are the scenarios of

252 events that had to occur to produce a change between the ancestral order to the order of the

253 current genomes (See Fig. S1). In many cases, a modest rearrangement from the ancestral

254 vertebrate gene order occurred at the base of a large group of organisms and is shared

255 broadly within that group, including: (1) a reverse transposition of $c o b, \operatorname{trn} T$, -trnP in

256 Actenopteri - Anguiliformes; (2) a reverse transposition of -trn $Q$ and -trnC, - $\operatorname{trn} Y$, a reverse

257 transposition of $-\operatorname{trn} S, \operatorname{trn} D, \operatorname{cox} 2, \operatorname{trn} K$, and a reversal of the region of $\operatorname{cox} 2$ to trnH in

258 Actinopteri - Pleuronectiformes; (3) a transposition of $\operatorname{trn} L$ in the Amphibia - Anura; (4) a

259 reverse transposition of nadl, trnI genes, a reversal of the region $\operatorname{trn} L$ to $n a d 1$, and a

260 reversal of the region $\operatorname{cox} 2$ to $t r n H$ in Reptilia - Serpentes; (5) a transposition of $t r n S$ in

261 Reptilia - Crocodilia; (6) a transposition of the region cob, trnT, -trnP in Aves; and (7) a

262 Tandem-Duplication-Random-Loss (TDRL) event for the region $\operatorname{trn} W$, - $\operatorname{trn} A$, - $\operatorname{trn} N$, -trnC,

$263-\operatorname{trn} Y$ in Mammalia - Marsupialia.

264 On the other hand, TreeREx is a useful algorithm for assigning rearrangements to the edges

265 of a given phylogenetic tree, with which we reconstruct the ancestral genetic orders at the 
266 interior nodes of the most rearranged orders and identify a significant number of

267 transpositions, reverse transpositions, inversions and Tandem-Duplication-Random-Loss

268 (TDRL) events (Supplementary Fig. S2). In Actinopteri - Saccopharyngiformes, TreeREx

269 detected that most nodes are inconsistent and that the most common event is TDRL (Fig.

270 S2A). In Actinopteri - Myctophiformes and Pleuronectiformes, TreeREx detected that

271 most nodes are consistent; the most common events being transpositions (Fig. S2B) and

272 TDRL, respectively (Fig. S2C). In Amphibia - Anura, TreeREx detected that nodes are

273 mostly consistent, with transpositions being the most common event causing

274 reorganizations in this order (Fig. S2D). In Reptilia - Lacertilia, TreeREx detected all the

275 nodes are consistent and the most common event is the inversions (Fig. S2E).

277 Discussion

278 Gene annotation errors in vertebrate mitochondrial genome

279 Due to the advance of sequencing techniques in the last two decades, hundreds of

280 mitochondrial genomes of different taxonomic groups of vertebrates have been deposited in

281 the NCBI database and then subsequently curated into RefSeq files. However, it has been

282 reported that the animal mitochondrial genomes in this database contain many errors of

283 gene annotation, the majority of which are readily detectable ${ }^{12,27,28}$. One source of these

284 errors may be from software that provides automated gene annotation ${ }^{28}$, but some

285 misannotations stem from simply failing to note the proper orientation of a gene or an

286 erroneous error of naming. Errors are also sometimes perpetuated by presuming that

287 previously made annotations are correct and then following this for a newly sequenced 
mtDNA, the so-calle "percolation of errors" ${ }^{12}$. Prada and Boore ${ }^{12}$ reported that $36.3 \%$ of mammalian mitochondrial genomes obtained from the NCBI database analyzed had annotation errors.

Our results, similar to those observed solely in mammals, show that tRNA genes are more susceptible to errors in gene notation (94.6\%) than other mitochondrial genes, with a higher error percentage in certain taxonomic groups (Actinopteri, Reptilia, and Aves). Popadin et al. ${ }^{29}$ suggest performing verification of tRNA gene annotations manually to ensure a higher level of accuracy in annotation, although it could also be done through a combination of semi-automated bioinformatics techniques ${ }^{12}$, where the curator would play an important role in detecting these errors. Due to the large number of mitochondrial genomes being reported annually in the database, the probability that these errors in gene notation will continue to spread is high, so a curation of the data by the scientific community is recommended ${ }^{30}$. NCBI is also encouraged to implement elementary error checking mechanisms when promoting a submitted sequence into their RefSeq database as described previously ${ }^{12,27}$.

\section{Genome Rearrangements and vertebrate mitochondrial genome Evolution}

Traditionally, vertebrate mitochondria have been considered to have a "conserved gene order" from primitive vertebrates (fish) to primates ${ }^{1,31,32}$. However, in some lineages, there is a variation in the rate of its reorganization. For example, within vertebrates, gene rearrangements have been found for some species of lizards, amphibians, fish, crocodilians, snakes, tuatara, and lamprey ${ }^{2,10,16}$. Nevertheless, in these studies, it is not identified which 
311 reorganization rate among them.

313 Our results show a differential reorganization proportion within and between taxonomic 314 classes, confirming that Reptilia, Amphibia, Petromyzonti (Lamprey), Mammalia, 315 Actinopteri and Aves, present a proportion between 4.85 and 0.65 , in order of highest to 316 lowest. For example, within the Reptilia class, Crocodylia and snakes present a specific 317 reorganization in comparison with the ancestral order of vertebrates, although it is 318 preserved within the same group. All Crocodylia have the order $\operatorname{trn} S$-trnH-trnL (derived 319 from an $\operatorname{trn} S$ transposition from the ancestral order of vertebrates), results consistent with 320 those reported previously ${ }^{2,33,34}$; observing a unique genetic architecture for all this group 321 (Alligatoridae and Crocodylidae). Similarly, most snakes have the order trnI-trnL-trnQ322 trnM, trnL (derived from a reverse transposition and reversal of the ancestral order of 323 vertebrates), which differs from the Viperidae with the order trnI-trnL-trnP-trnQ-trnM 324 (derived from a trnP translocation), similar results with those reported previously ${ }^{2,34,35}$. 325 However, our results show that the two species of snakes belonging to the Typhlopidae 326 family (Amerotyphlops reticulatus and Indotyphlops braminus), present the ancestral order 327 of vertebrates and not that of other snakes, consistent with an earlier report ${ }^{36}$. In contrast, 328 within the suborder Lacertilia (Reptilia), we observe that some taxonomic families such as 329 Agamidae, Chamaelonidae and some species of the family Gekkonidae, present a higher 330 rate of reorganization than others families such as Iguanidae or Lacertidae that retain the 331 ancestral vertebrate order ${ }^{34,37}$. 
332 Amphibians have been reported to be a more conservative group compared to reptiles ${ }^{2}$.

333 However, our results show that within amphibians, the Anura order (124 species analyzed)

334 is more reorganized, with a total of 103 species showing at least one reorganization event

335 and only 21 with the ancestral vertebrate order. Of these reorganized species, most (86)

336 share different gene orders, and the rest have unique architectures (18). Xia et al. ${ }^{6}$ presents

337 the $c o b$, trnL, $\operatorname{trn} T$, $-\operatorname{trn} P$ gene order as an extensive reorganization in anurans

338 (Neobatrachia), our results confirm this, and that the Anura mitochondrial genome presents

339 greater variability in terms of genetic order than in comparison with other amphibians.

340 Previous studies have postulated that the genetic order nad6-trnT-trnE-cob-trnP is common

341 among lampreys ${ }^{2,38}$, known to be the earliest diverged vertebrates with a time of

342 divergence inferred to be 550 mya $^{39}$. Although our results confirm the presence of this

343 reorganization in two species of lampreys (Lethenteron camtschaticum and Petromyzon

344 marinus) in the family Petromyzontidae, the three remaining species of this family with a

345 reported mtDNA gene arrangement and the one species in the Geotriidae family retain the

346 vertebrate ancestral gene order, so it is not correct to assert that it is an ancestral character

347 of all lampreys.

348 According to Satoh et al., ${ }^{10}$, most of the fishes had the typical gene order widely shared

349 among vertebrate mt genomes, noting that only $14 \%(35 / 250)$ of these species observed

350 have at least one rearrangement, a percentage over three times as high $(4.1 \% ; 52 / 1255)$ as

351 that presented by Gong et al., ${ }^{40}$. Although our results show a relatively low proportion,

352 similar to those previously published, some taxonomic orders such as Anguilliformes,

353 Saccopharyngiformes, Myctophiformes, Gadiformes, Batrachoidiformes,

354 Pleuronectiformes, Perciformes, and Perciformes (and some listed as sedis mutabilis) are 
highly reorganized in comparison with other orders in fish. Many of such gene order are

356 unique to a specific taxon, but some are shared polyphyletically between distantly related

357 species.

358 Our results confirm that the majority of species within the class Aves share the cob, trnT, -

$359 \operatorname{trn} P,-n a d 6,-\operatorname{trn} E$ rearrangement from the ancestral vertebrate arrangement as described in

360 early work ${ }^{41}$. In addition to this, multiple independent rearrangements have occurred in

361 some species of birds, including genetic duplications of $\operatorname{trn} E$, $\operatorname{trn} T, \operatorname{trn} P, \mathrm{CR}$ (Control

362 Region) and cob pseudogenes as has been previously reported ${ }^{9,42}$. This work clarifies that

363 these duplications are concentrated in certain taxonomic groups such as the family

364 Ardeidae (Pelecaniformes), Procellariiformes and Suliformes, marine aquatic birds with

365 great diving capacity, suggesting this gene order is the ancestral pattern within these birds

366 and persisted in most lineages perhaps through concerted evolution ${ }^{42}$. According to Gibb et

367 al., ${ }^{43}$, it is very possible that in species of birds of different orders, they have hidden

368 duplications in the genome that also include the control region and cannot be observed

369 because the genome assembly programs for short sequencing reads artifactually collapse

370 these regions. Nevertheless, further physiological and molecular analyses are necessary to

371 assess the potential selective advantages of the mitogenome duplications ${ }^{44}$.

373 Convergence in a Hotspot of Gene Rearrangement

374 Genomes with small size, such as mitochondrial genomes, have fewer mutational targets

375 compared to genomes with large sizes (such as the nuclear genome), so convergent

376 evolution through homologous site mutations is expected to occur more commonly in 
377 smaller genomes ${ }^{45}$. Therefore, homoplastic gene orders have been identified in vertebrate 378 mitochondrial genomes ${ }^{13,46}$.

379 Our results, as found in previous analysis, have shown that the mitochondrial genome of 380 vertebrates, in certain taxonomic groups, have a considerable proportion of reorganization.

381 Most of these rearrangements involve tRNA genes, nad5, and/or the D-loop region, as has 382 been observed for smaller studies ${ }^{2,3,13-15,37,47}$. There are constraints and 'hotspots' for 383 rearrangement, making evolutionary convergence more likely than it would be if there were 384 equal probabilities of change at each gene position ${ }^{11}$. In this work, the identification of 385 three "hot spots" (trnL, nadl, $\operatorname{trnI},-\operatorname{trn} Q, \operatorname{trn} M ; \operatorname{trn} W,-\operatorname{trn} A,-\operatorname{trn} N$, -trnC and -nad6, -trnE, $386 \operatorname{cob}, \operatorname{trn} T,-\operatorname{trn} P$ ) in the mitochondrial genome of vertebrates, in certain lineages, could 387 increase the possibility of evolutionary convergences between different groups of species. 388 The large number of species involved in the convergences (764) observed in this work, 389 favors the view that convergent evolution is a general phenomenon of the vertebrate 390 mtDNA, at least in these hotspot regions, as had been earlier predicted ${ }^{8,11}$. Our results 391 support that convergences occur in two cases, (A) in which nearest neighbor tRNA genes 392 exchange their position as is the case in convergences 4, 6, 7 and 8 and (B) in genes 393 flanking either of the two origins of replication as occurs in convergences 1, 2, 3, 5 9, 10 394 and 11 reported in this study.

\section{Conclusion}

397 The analysis of vertebrate mitochondrial genomes available in the database that we 398 performed in this work identified a high error percentage in gene annotations, in addition, it 
399 shows a number of significant rearrangement events (especially in tRNA genes) in these

400 organisms, contrary to what has been believed for many years. In addition, we show that

401 the types and frequency of rearrangements in genomes behave differently between

402 vertebrate classes and between taxonomic orders of classes. We report new convergence

403 events in the gene order among vertebrate mitogenome in this paper.

404

405 Acknowledgements

406 We thank the University of Tolima for supporting this research. The first author thanks to

407 Oficina de Investigaciones y Desarrollo Científico de la Universidad del Tolima by the

408 early researcher scholarship.

409

410 Author Contributions

411 MPML: Methodology, Software, Validation, Formal analysis, Investigation and Data

412 Curation for Amphibian and Reptile, Writing - Original Draft, Writing - Review \& Editing

413 MAMC: Methodology, Software, Validation, Formal analysis, Investigation and Data

414 Curation for mammals.

415 MOC: Software, Validation, Formal analysis, Investigation and Data Curation for fishs.

416 NSM: Software, Validation, Formal analysis, Investigation and Data Curation for birds.

417 JLB: Methodology, Validation, Writing - Original Draft, Writing - Review \& Editing 
418 CFPQ: Conceptualization, Methodology, Software, Validation, Formal analysis,

419 Investigation, Writing - Original Draft, Writing - Review \& Editing Visualization,

420 Supervision, Project administration Funding acquisition.

421

422 Ethics approval and consent to participate

423 There was no animal experimentation undertaken in this study.

424

425 Competing interests

426 The authors declare that they have no competing interests.

427

$428 \quad$ References

4291 Boore, J. L. Animal mitochondrial genomes. Nucleic acids research 27, 1767-1780, $430 \quad$ doi:10.1093/nar/27.8.1767 (1999).

4312 Pereira, S. L. Mitochondrial genome organization and vertebrate phylogenetics.

$432 \quad$ Genetics and Molecular Biology 23, 745-752 (2000).

4333 Formenti, G. et al. Complete vertebrate mitogenomes reveal widespread gene

434 duplications and repeats. bioRxiv, 2020.2006.2030.177956,

435 doi:10.1101/2020.06.30.177956 (2020).

4364 Zhang, J. et al. qMGR: A new approach for quantifying mitochondrial genome

437 rearrangement. Mitochondrion 52, 20-23, doi:10.1016/j.mito.2020.02.004 (2020).

4385 Gong, L. et al. Novel gene rearrangement pattern in Cynoglossus melampetalus 439 mitochondrial genome: New gene order in genus Cynoglossus (Pleuronectiformes: 
$441 \quad$ 1240, doi:10.1016/j.ijbiomac.2020.02.017 (2020).

4426 Xia, Y., Zheng, Y., Murphy, R. W. \& Zeng, X. Intraspecific rearrangement of

443 mitochondrial genome suggests the prevalence of the tandem duplication-random

444 loss (TDLR) mechanism in Quasipaa boulengeri. BMC genomics 17, 965,

445 doi:10.1186/s12864-016-3309-7 (2016).

4467 Al Arab, M., Bernt, M., Höner Zu Siederdissen, C., Tout, K. \& Stadler, P. F.

447 Partially local three-way alignments and the sequence signatures of mitochondrial

448 genome rearrangements. Algorithms Mol Biol 12, 22, doi:10.1186/s13015-017-

449 0113-0 (2017).

4508 Boore, J. L. in Comparative genomics 133-147 (Springer, 2000).

4519 Mindell, D. P., Sorenson, M. D. \& Dimcheff, D. E. Multiple independent origins of

452 mitochondrial gene order in birds. Proceedings of the National Academy of Sciences

$453 \quad$ 95, 10693-10697 (1998).

45410 Satoh, T. P., Miya, M., Mabuchi, K. \& Nishida, M. Structure and variation of the 455 mitochondrial genome of fishes. BMC genomics 17, 719, doi:10.1186/s12864-016456 3054-y (2016).

45711 Boore, J. L. \& Brown, W. M. Big trees from little genomes: mitochondrial gene 458 order as a phylogenetic tool. Current opinion in genetics \& development 8, 668-674, doi:10.1016/s0959-437x(98)80035-x (1998).

46012 Prada, C. F. \& Boore, J. L. Gene annotation errors are common in the mammalian 461 mitochondrial genomes database. BMC genomics 20, 73, doi:10.1186/s12864-0195447-1 (2019). 
46313 San Mauro, D., Gower, D. J., Zardoya, R. \& Wilkinson, M. A hotspot of gene order 464 rearrangement by tandem duplication and random loss in the vertebrate 465 mitochondrial genome. Molecular biology and evolution 23, 227-234, 466 doi:10.1093/molbev/msj025 (2006).

46714 Zhong, J., Li, G., Liu, Z. Q., Li, Q. W. \& Wang, Y. Q. [Gene rearrangement of 468 mitochondrial genome in the vertebrate]. Yi chuan xue bao = Acta genetica Sinica 469 32, 322-330 (2005).

47015 Gissi, C., Iannelli, F. \& Pesole, G. Evolution of the mitochondrial genome of $471 \quad$ Metazoa as exemplified by comparison of congeneric species. Heredity 101, 301320, doi:10.1038/hdy.2008.62 (2008).

47316 Sankoff, D. et al. Gene order comparisons for phylogenetic inference: evolution of 474 the mitochondrial genome. Proceedings of the National Academy of Sciences of the United States of America 89, 6575-6579, doi:10.1073/pnas.89.14.6575 (1992).

47617 Kearse, M. et al. Geneious Basic: an integrated and extendable desktop software 477 platform for the organization and analysis of sequence data. Bioinformatics 28, $478 \quad$ 1647-1649(2012).

47918 Bernt, M. et al. MITOS: improved de novo metazoan mitochondrial genome $480 \quad$ annotation. Molecular phylogenetics and evolution 69, 313-319, 481 doi:10.1016/j.ympev.2012.08.023 (2013).

48219 Chan, P. P. \& Lowe, T. M. tRNAscan-SE: Searching for tRNA Genes in Genomic 483 Sequences. Methods Mol Biol 1962, 1-14, doi:10.1007/978-1-4939-9173-0_1 (2019).

48520 Babicki, S. et al. Heatmapper: web-enabled heat mapping for all. Nucleic acids research 44, W147-153, doi:10.1093/nar/gkw419 (2016). 
48721 Amemiya, C. T. et al. Analysis of the African coelacanth genome sheds light on tetrapod evolution. Nature 496, 311, doi:10.1038/nature12027 (2013).

48922 Bernt, M., Merkle, D. \& Middendorf, M. in RECOMB International Workshop on $490 \quad$ Comparative Genomics. 143-157 (Springer).

49123 Darling, A. C., Mau, B., Blattner, F. R. \& Perna, N. T. Mauve: multiple alignment 492 493 doi:10.1101/gr.2289704 (2004).

49424 Rambaut, A. (2014).

$49525 \quad$ Hannenhalli, S. \& Pevzner, P. A. in Proceedings of IEEE 36th annual foundations 496 of computer science. 581-592 (IEEE).

49726 Tesler, G. GRIMM: genome rearrangements web server. Bioinformatics 18, 492498 493, doi:10.1093/bioinformatics/18.3.492 (2002).

49927 Boore, J. L. Requirements and standards for organelle genome databases. Omics 10, 500 119-126, doi:10.1089/omi.2006.10.119 (2006).

50128 Donath, A. et al. Improved annotation of protein-coding genes boundaries in 502 metazoan mitochondrial genomes. Nucleic acids research 47, 10543-10552, 503 doi:10.1093/nar/gkz833 (2019).

50429 Popadin, K. Y., Mamirova, L. A. \& Kondrashov, F. A. A manually curated database 505 of tetrapod mitochondrially encoded tRNA sequences and secondary structures.

506 BMC Bioinformatics 8, 441, doi:10.1186/1471-2105-8-441 (2007).

50730 Brenner, S. E. Errors in genome annotation. Trends Genet 15, 132-133, 508 doi:10.1016/s0168-9525(99)01706-0 (1999).

50931 Anderson, S. et al. Sequence and organization of the human mitochondrial genome. 510 Nature 290, 457-465, doi:10.1038/290457a0 (1981). 
51132 Noack, K., Zardoya, R. \& Meyer, A. The complete mitochondrial DNA sequence of 512 the bichir (Polypterus ornatipinnis), a basal ray-finned fish: ancient establishment of 513 the consensus vertebrate gene order. Genetics 144, 1165-1180 (1996).

51433 Janke, A. \& Arnason, U. The complete mitochondrial genome of Alligator 515 mississippiensis and the separation between recent archosauria (birds and 516 crocodiles). Molecular biology and evolution 14, 1266-1272, 517 doi:10.1093/oxfordjournals.molbev.a025736 (1997).

51834 Kumazawa, Y. \& Nishida, M. Variations in mitochondrial tRNA gene organization 519 of reptiles as phylogenetic markers. Molecular biology and evolution 12, 759-772, 520 doi:10.1093/oxfordjournals.molbev.a040254 (1995).

52135 Kumazawa, Y., Ota, H., Nishida, M. \& Ozawa, T. Gene rearrangements in snake 522 mitochondrial genomes: highly concerted evolution of control-region-like sequences duplicated and inserted into a tRNA gene cluster. Molecular biology and

52536 Yan, J., Li, H. \& Zhou, K. Evolution of the mitochondrial genome in snakes: gene 526 rearrangements and phylogenetic relationships. BMC genomics $\mathbf{9}, 569$, 527 doi:10.1186/1471-2164-9-569 (2008).

52837 Macey, J. R., Larson, A., Ananjeva, N. B., Fang, Z. \& Papenfuss, T. J. Two novel 529 gene orders and the role of light-strand replication in rearrangement of the vertebrate mitochondrial genome. Molecular biology and evolution 14, 91-104, doi:10.1093/oxfordjournals.molbev.a025706 (1997).

53238 Delarbre, C. et al. The complete nucleotide sequence of the mitochondrial DNA of 533 the agnathan Lampetra fluviatilis: bearings on the phylogeny of cyclostomes. 
55445 Stern, D. L. The genetic causes of convergent evolution. Nat Rev Genet 14, 751-

555

Molecular biology and evolution 17, 519-529, doi:10.1093/oxfordjournals.molbev.a026332 (2000).

39 Lee, W. J. \& Kocher, T. D. Complete sequence of a sea lamprey (Petromyzon marinus) mitochondrial genome: early establishment of the vertebrate genome organization. Genetics 139, 873-887 (1995).

40 Gong, L., Shi, W., Si, L. Z. \& Kong, X. Y. [Rearrangement of mitochondrial genome in fishes]. Dong wu хие yan jiu = Zoological research 34, 666-673 (2013).

41 Desjardins, P. \& Morais, R. Sequence and gene organization of the chicken mitochondrial genome. A novel gene order in higher vertebrates. Journal of molecular biology 212, 599-634, doi:10.1016/0022-2836(90)90225-b (1990).

42 Zhou, X., Lin, Q., Fang, W. \& Chen, X. The complete mitochondrial genomes of sixteen ardeid birds revealing the evolutionary process of the gene rearrangements. BMC genomics 15, 573, doi:10.1186/1471-2164-15-573 (2014).

43 Gibb, G. C. et al. New Zealand Passerines Help Clarify the Diversification of Major Songbird Lineages during the Oligocene. Genome biology and evolution 7, 29832995, doi:10.1093/gbe/evv196 (2015).

44 Urantówka, A. D., Kroczak, A. \& Mackiewicz, P. New view on the organization and evolution of Palaeognathae mitogenomes poses the question on the ancestral gene rearrangement in Aves. BMC genomics 21, 874, doi:10.1186/s12864-02007284-5 (2020). 764, doi:10.1038/nrg3483 (2013).

46 Macey, J. R., Papenfuss, T. J., Kuehl, J. V., Fourcade, H. M. \& Boore, J. L. Phylogenetic relationships among amphisbaenian reptiles based on complete 

571 Trans. -Translocations.

\section{List of tables and figures}

47 Pääbo, S., Thomas, W. K., Whitfield, K. M., Kumazawa, Y. \& Wilson, A. C. Rearrangements of mitochondrial transfer RNA genes in marsupials. J Mol Evol 33, 426-430, doi:10.1007/bf02103134 (1991).

Table 1. Number and distribution of analyzed mitochondrial genomes with summary of types of deletions, duplications, inversions, translocations that have been reported in GenBank correctly or as gene annotation errors detected in this work. * The order has no species with the ancestral gene order. A: Ancestral architecture, in some taxonomic groups in addition to the different architectures (with rearrangements) organisms with the ancestral organization can also be found. Dupli. - Duplications, Dele. -Deletions, Inver. - Inversions,

572 Table 2. Gene Arrangement: Convergence in the mitochondrial genome of Vertebrata.

573 Fig. 1. Gene rearrangement proportion values for each of the vertebrate classes sampled.

574 Fig. 2. Heat map of gene rearrangement analysis among vertebrate classes. Phylogenetic 575 relationships are as interpreted in ${ }^{21}$. Dark green colors show a low proportion of change 576 and red colors show a high number of rearrangement events for each of the individual 577 genes within each taxonomic order that exhibited rearrangements in mitochondrial 578 sequences. Orange diamonds show the number of convergences detected in that taxonomic 
579 order; aquamarine blue circles indicate that a CREx representation was performed for that 580 taxonomic order.

581 Fig. 3. Evolutionary convergence of mitochondrial gene order rearrangements. This shows

582 only the subset that are rearranged; all other genes share the ancestral arrangement. Arrows 583 show transcriptional orientation. tRNA-encoding genes are labeled with the one-letter code 584 for the corresponding amino acid. In parentheses are the number of species involved in the 585 convergence.

586

\section{Supplementary Material}

588 Table S1. Analysis of gene arrangements of vertebrate mitochondrial genome. NCBI with 589 Reference IDs shown for each species. The numeral in parentheses indicates the number of 590 species belonging to each taxonomic group. Each gene is assigned a number 1 to 37 at the 591 top of the Table which is then used to describe the annotated gene arrangement for each 592 species. Each gene is transcribed left-to-right as shown except for those with a minus (-)

593 symbol to indicate opposite orientation. The ancestral gene order has been inferred to be as 594 postulated by ${ }^{1}$. Highlighting indicates all deviations from that ancestral arrangement as 595 confirmed by the bioinformatics tools used in this study, with being yellow to gene 596 inversion-translocation, light blue to gene duplication, purple to pseudogenes and red to 597 gene deletions. 
599 Table S2. Mitochondrial genome rearrangement rate in each gene by taxonomic order in

600 Hexapoda. (M) manual and qMGR rearrangement rate analysis are indicated by each

601 mitochondrial gene.

602 Fig. S1. Parsimonious evolutionary scenario leading to the extant gene orders in vertebrate

603 by CREx analysis. Arrows show transcriptional orientation. tRNA-encoding genes are

604 labeled with the one-letter code for the corresponding amino acid. (A) Actenopteri-

605 Anguiligormes partial ancestral order, (B) Actenopteri-Pleuronectiformes ancestral order,

606 (C) Amphibia-Anura partial ancestral, (D) Reptilia-Lacertilia-Chamaelonidae and

607 Agamidae ancestor order, (E) Reptilia-Serpentes ancestor order, (F) Reptilia-Crocodilia

608 ancestor order, (G) Aves ancestral order, (H) Mammalia-Marsupialia ancestor order. Each

609 evolutionary event (reversal, transposition and reversed translocations) is signaled to

610 transform the ancestral genome into the derived mitochondrial genome. The superscript

611 indicates the taxonomic orders that have partial ancestor (ancestor with reorganizations and 612 with ancestral order).

614 Fig. S2. TreeREx analysis for vertebrate class. (A) Actinopteri - Saccopharyngiformes, (B)

615 Actinopteri - Myctophiformes, (C) Actinopteri, (D) Amphibia - Anura. The rearrangements

616 on the branches are given as Transposition, Inversion, Inverse transposition and Tandem-

617 Duplication-Random-Loss events (TDRLs). 
621 Table 1. Number and distribution of analyzed mitochondrial genomes with summary of types of deletions, duplications, inversions, translocations

622 that have been reported in GenBank correctly or as gene annotation errors detected in this work.

\begin{tabular}{|c|c|c|c|c|c|c|c|c|c|c|}
\hline Class & $\begin{array}{c}\text { No. } \\
\text { orders }\end{array}$ & $\begin{array}{c}\text { No. } \\
\text { species }\end{array}$ & $\begin{array}{c}\text { No. of } \\
\text { different } \\
\text { genomes } \\
\text { within the } \\
\text { order }\end{array}$ & $\begin{array}{c}\text { Genes } \\
\text { differing in } \\
\text { rearrangement }\end{array}$ & $\begin{array}{c}\text { Numer } \\
\text { confirmed }\end{array}$ & Dup & Del & $\begin{array}{l}\text { Inv- } \\
\text { tra }\end{array}$ & $\begin{array}{l}\text { Numer } \\
\text { refuted }\end{array}$ & $\begin{array}{c}\% \text { of } \\
\text { reorganization }\end{array}$ \\
\hline Myxini & 1 & 2 & $\mathrm{~A}$ & 0 & 0 & 0 & 0 & 0 & 0 & 0 \\
\hline Petromyzonti & 1 & 6 & $1+\mathrm{A}$ & 6 & 6 & 0 & 0 & 6 & 0 & 2.70 \\
\hline Elasmobranchii & 12 & 74 & A & 2 & 0 & 0 & 0 & 0 & 2 & 0 \\
\hline Holocephali & 1 & 5 & A & 0 & 0 & 0 & 0 & 0 & 0 & 0 \\
\hline Cladistii & 1 & 2 & A & 0 & 0 & 0 & 0 & 0 & 0 & 0 \\
\hline Actinopteri & 59 & 1259 & $60+A$ & 751 & 628 & 25 & 9 & 594 & 123 & 1.61 \\
\hline Coelacanthi & 1 & 1 & A & 0 & 0 & 0 & 0 & 0 & 0 & 0 \\
\hline Dipneusti & 1 & 3 & A & 0 & 0 & 0 & 0 & 0 & 0 & 0 \\
\hline Amphibia & 3 & 241 & $34+\mathrm{A}$ & 292 & 262 & 55 & 4 & 203 & 30 & 3.27 \\
\hline Reptilia & 6 & 314 & $26+A$ & 564 & 475 & 30 & 4 & 441 & 89 & 4.85 \\
\hline Aves & 28 & 620 & $15^{*}$ & 149 & 72 & 68 & 4 & 0 & 77 & 0.65 \\
\hline \multirow[t]{2}{*}{ Mammalia } & 29 & 304 & $2+\mathrm{A}$ & 187 & 119 & 0 & 0 & 119 & 68 & 1.66 \\
\hline & & 2831 & - & 1951 & 1562 & 178 & 21 & 1363 & 389 & \\
\hline
\end{tabular}


624 Table 2. Gene Arrangement: Convergence in the mitochondrial genome of Vertebrata.

\begin{tabular}{|c|c|c|c|}
\hline Convergence & Taxonomic level & Order & $\begin{array}{c}\mathrm{N} . \\
\text { genome }\end{array}$ \\
\hline \multirow{2}{*}{$\begin{array}{l}\text { Convergence } 1(- \\
\operatorname{trn} A,-\operatorname{trn} C, \operatorname{trn} W,- \\
\operatorname{trn} N)\end{array}$} & Siphonops annulatus & $\begin{array}{c}\text { Gymnophiona } \\
\text { (Amphibia) }\end{array}$ & 1 \\
\hline & & $\begin{array}{l}\text { Marsupialia } \\
\text { (Mammalia) }\end{array}$ & 29 \\
\hline \multirow{19}{*}{$\begin{array}{c}\text { Convergence } 2 \\
(c o b, \operatorname{trn} T,-n a d 6,- \\
\operatorname{trn} E)\end{array}$} & Coloconger cadenati & \multirow{14}{*}{$\begin{array}{c}\text { Anguiliformes } \\
\text { (Actinopteri) }\end{array}$} & \multirow{14}{*}{14} \\
\hline & Ariosoma shiroanago & & \\
\hline & Paraconger notialis & & \\
\hline & Conger japonicus & & \\
\hline & Congriscus sp. & & \\
\hline & Heteroconger hassi & & \\
\hline & Derichthys serpentinus & & \\
\hline & Nessorhamphus ingolfianus & & \\
\hline & Cynoponticus ferox & & \\
\hline & Muraenesox bagio & & \\
\hline & Facciolella oxyrhyncha & & \\
\hline & Hoplunnis punctata & & \\
\hline & Nettastoma parviceps & & \\
\hline & Ophisurus macrorhynchos & & \\
\hline & Chaenocephalus aceratus & \multirow{3}{*}{$\begin{array}{l}\text { Perciformes } \\
\text { (Actinopteri) }\end{array}$} & \multirow{3}{*}{3} \\
\hline & Chionodraco hamatus & & \\
\hline & Notothenia coriiceps & & \\
\hline & Aneides flavipunctatus & \multirow{2}{*}{ Caudata (Amphibia) } & \multirow{2}{*}{2} \\
\hline & Stereochilus marginatus & & \\
\hline \multirow{3}{*}{$\begin{array}{c}\text { Convergence } 3 \\
(\text { trnT, -trnP, -nad6, } \\
\text {-trnE) }\end{array}$} & Pagothenia borchgrevinki & $\begin{array}{l}\text { Perciformes } \\
\text { (Actinopteri) }\end{array}$ & 1 \\
\hline & Rhineura floridana & $\begin{array}{c}\text { Amphisbaenia } \\
\text { (Reptilia) }\end{array}$ & 1 \\
\hline & & Aves & 591 \\
\hline \multirow{12}{*}{$\begin{array}{l}\text { Convergence } 4(- \\
\text { trnQ, trnI, trnM) }\end{array}$} & Kurtus gulliveri & $\begin{array}{l}\text { Kurtiformes } \\
\text { (Actinopteri) }\end{array}$ & 1 \\
\hline & Ponticola kessleri & $\begin{array}{l}\text { Gobiiformes } \\
\text { (Actinopteri) }\end{array}$ & 1 \\
\hline & Brookesia decaryi & \multirow{10}{*}{ Lacertilia (Reptilia) } & \multirow{10}{*}{29} \\
\hline & Chamaeleo africanus & & \\
\hline & Chamaeleo arabicus & & \\
\hline & Chamaeleo calcaricarens & & \\
\hline & Chamaeleo calyptratus & & \\
\hline & Chamaeleo chamaeleon & & \\
\hline & Chamaeleo dilepis & & \\
\hline & Chamaeleo monachus & & \\
\hline & Chamaeleo zeylanicus & & \\
\hline & Furcifer oustaleti & & \\
\hline
\end{tabular}




\begin{tabular}{|c|c|c|c|}
\hline & Kinyongia fischeri & & \\
\hline & Trioceros melleri & & \\
\hline & Acanthosaura armata & & \\
\hline & Acanthosaura lepidogaster & & \\
\hline & Chlamydosaurus kingii & & \\
\hline & Hydrosaurus amboinensis & & \\
\hline & Leiolepis boehmei & & \\
\hline & Leiolepis guttata & & \\
\hline & Phrynocephalus albolineatus & & \\
\hline & Phrynocephalus axillaris & & \\
\hline & Phrynocephalus grumgrzimailoi & & \\
\hline & Phrynocephalus guinanensis & & \\
\hline & Phrynocephalus helioscopus & & \\
\hline & Phrynocephalus mystaceus & & \\
\hline & Phrynocephalus putjatai & & \\
\hline & Pogona vitticeps & & \\
\hline & Pseudotrapelus sinaitus & & \\
\hline & Uromastyx benti & & \\
\hline & Xenagama taylori & & \\
\hline \multirow{4}{*}{$\begin{array}{l}\text { Convergence } 5 \text { (- } \\
\text { nad6, cob, trnT },- \\
\quad \operatorname{trn} P, \text { - trnE) }\end{array}$} & Cetonurus globiceps & \multirow{3}{*}{$\begin{array}{l}\text { Gadiformes } \\
\text { (Actinopteri) }\end{array}$} & \multirow{3}{*}{3} \\
\hline & Coelorinchus kishinouyei & & \\
\hline & Ventrifossa garmani & & \\
\hline & Uroplatus fimbriatus & Lacertilia (Reptilia) & 1 \\
\hline \multirow{3}{*}{$\begin{array}{l}\text { Convergence } 6 \\
\text { (nadl, trnI, trnL) }\end{array}$} & Squalogadus modificatus & \multirow{2}{*}{$\begin{array}{c}\text { Gadiformes } \\
\text { (Actinopteri) }\end{array}$} & 1 \\
\hline & Trachyrincus murrayi & & 1 \\
\hline & & $\begin{array}{c}\text { Alethinophidia- } \\
\text { Serpentes (Reptilia) }\end{array}$ & 57 \\
\hline \multirow{2}{*}{$\begin{array}{l}\text { Convergence } 7 \\
(\operatorname{trn} S, \operatorname{trn} H)\end{array}$} & Aulorhynchus flavidus & $\begin{array}{l}\text { Perciformes } \\
\text { (Actinopteri) }\end{array}$ & 1 \\
\hline & & $\begin{array}{l}\text { Crocodylia } \\
\text { (Reptilia) }\end{array}$ & 18 \\
\hline \multirow[b]{2}{*}{$\begin{array}{c}\text { Convergence } 8 \\
(t r n D,-\operatorname{trn} S)\end{array}$} & Normichthys operosus & $\begin{array}{l}\text { Alepocephaliformes } \\
\text { (Actinopteri) }\end{array}$ & 1 \\
\hline & Ambassis gymnocephalus & $\begin{array}{c}\text { Perciformes 'sedis } \\
\text { mutabilis' } \\
\text { (Actinopteri) }\end{array}$ & 1 \\
\hline \multirow{2}{*}{$\begin{array}{l}\text { Convergence } 9 \\
(\operatorname{cob},-\operatorname{trn} P, \operatorname{trn} T)\end{array}$} & Dallia pectoralis & $\begin{array}{l}\text { Esociformes } \\
\text { (Actinopteri) }\end{array}$ & 1 \\
\hline & Rudarius ercodes & $\begin{array}{l}\text { Tetraodontiformes } \\
\text { (Actinopteri) }\end{array}$ & 1 \\
\hline \multirow{2}{*}{$\begin{array}{l}\text { Convergence } 10 \\
\text { (-trnP deletion) }\end{array}$} & Trichiurus japonicus & $\begin{array}{l}\text { Scombriformes } \\
\text { (Actinopteri) }\end{array}$ & 1 \\
\hline & Hapalogenys analis & $\begin{array}{l}\text { Acanthuriformes } \\
\text { (Actinopteri) }\end{array}$ & 1 \\
\hline
\end{tabular}




\begin{tabular}{|l|l|c|r|}
\hline & Lampris guttatus & $\begin{array}{c}\text { Lampriformes } \\
\text { (Actinopteri) }\end{array}$ & 1 \\
\hline \multirow{2}{*}{$\begin{array}{c}\text { Convergence 11 (- } \\
\text { trnP duplication) }\end{array}$} & Clinocottus analis & $\begin{array}{c}\text { Perciformes } \\
\text { (Actinopteri) }\end{array}$ & 1 \\
\cline { 2 - 4 } & Boulengerula taitana & $\begin{array}{c}\text { Gymnophiona } \\
\text { (Amphibia) }\end{array}$ & 1 \\
\hline \multicolumn{2}{|l}{} & Total & 764 \\
\hline
\end{tabular}

625 
Figure 1

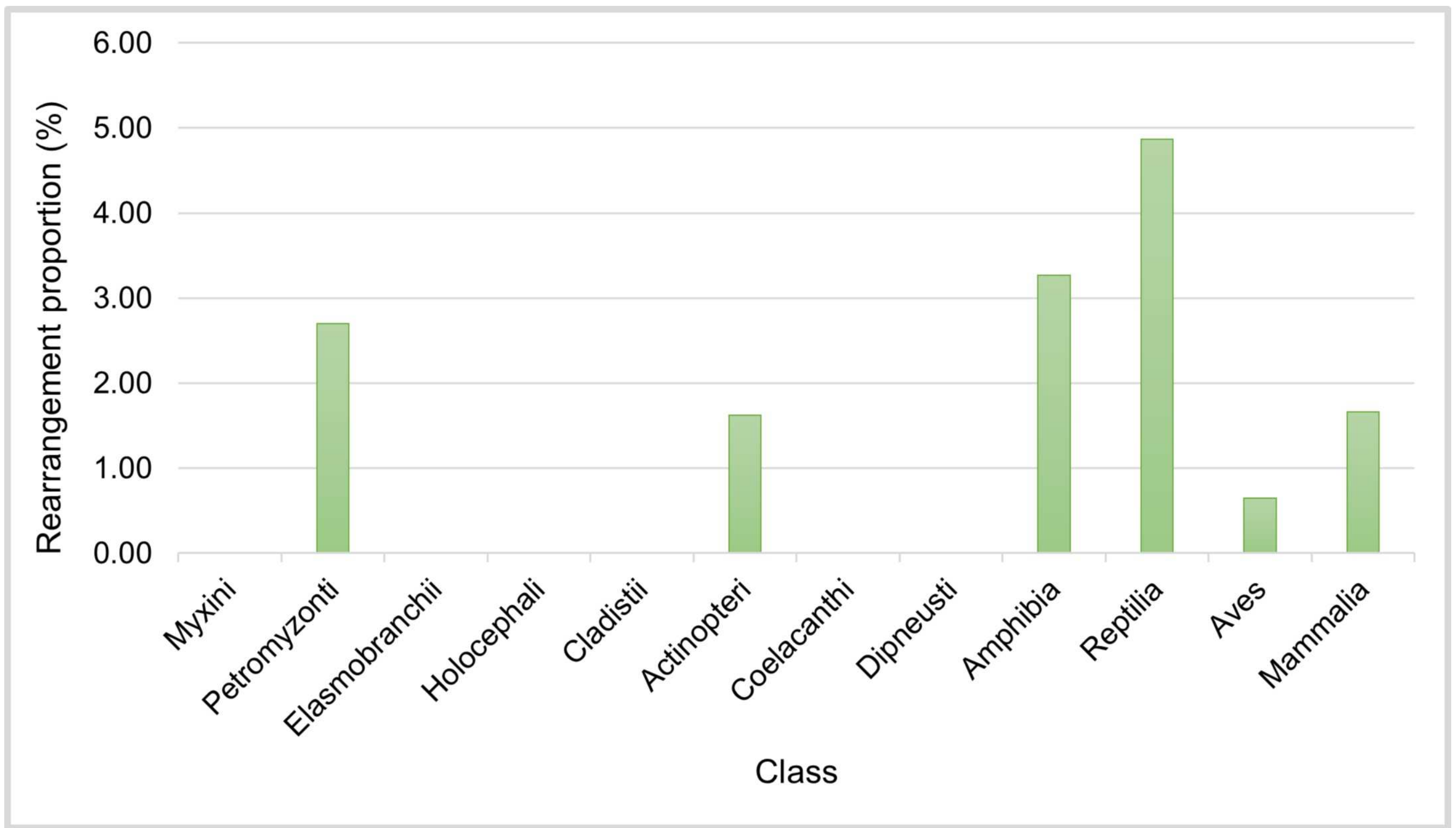




\section{Figure 2}

\begin{tabular}{|c|c|}
\hline Convergences & Values \\
\hline CREx & \\
\hline
\end{tabular}

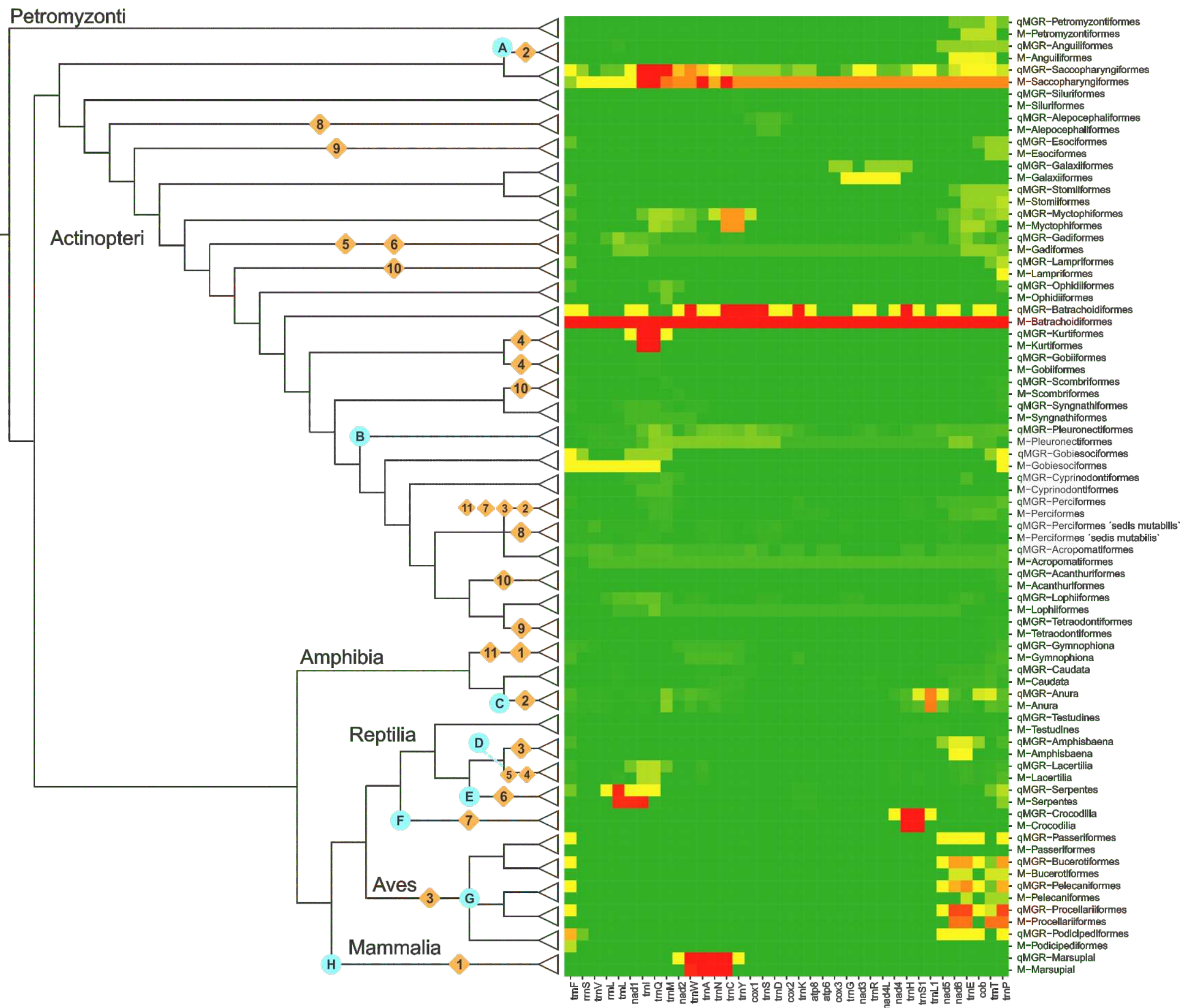


Figure 3

Ancestral architecture of reference for vertebrates

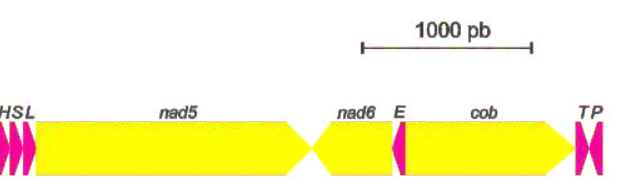

Convergences present in vertebrates. The number of species involved is indicated in parentheses

Convergence 1. Amphibia: Gymnophiona (1) - Mammalia: Marsupialia (29)

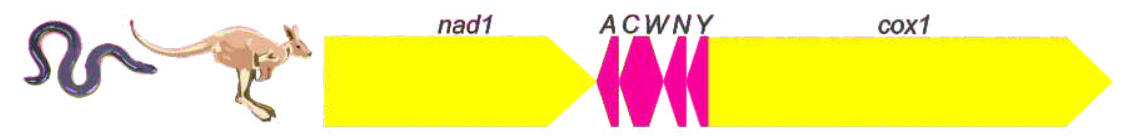

Convergence 2. Actinopteri: Anguilliformes (14), Perciformes (3) - Amphibia: Caudata (2)

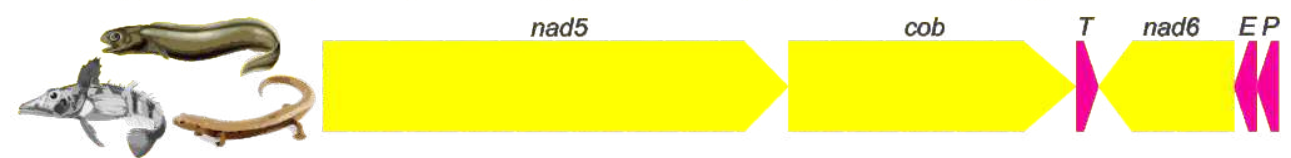

Convergence 3. Actinopteri: Perciformes (1) - Amphibia: Amphisbaenia (1) - Aves (591)

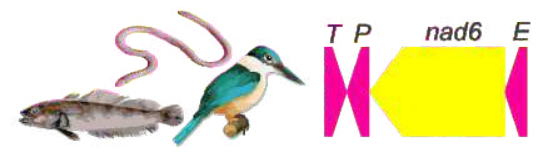

Convergence 4. Actinopteri: Kurtiformes (1), Gobiliformes (1) - Reptilia: Lacertilia (29)

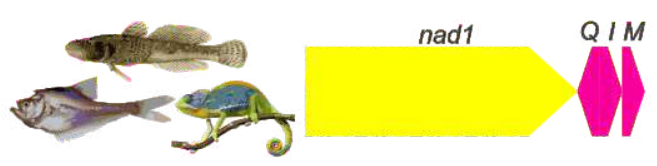

Convergence 5. Actinopteri: Gadiformes (3) - Reptilia: Lacertilia (1)

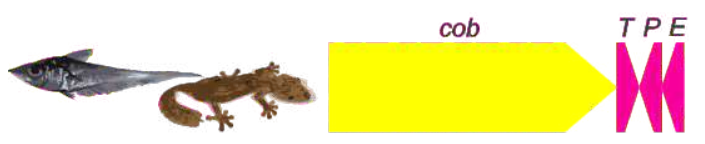

Convergence 6. Actinopteri: Gadiformes (2) - Reptilia: Serpentes (57)

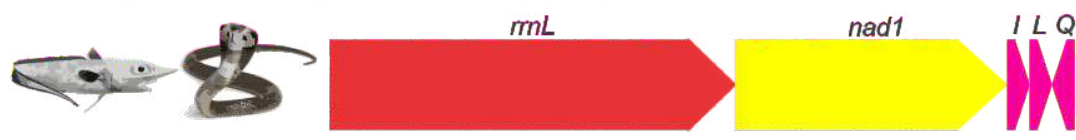

Convergence 7. Actinopteri: Perciformes (1) - Reptilia: Crocodilia (18)

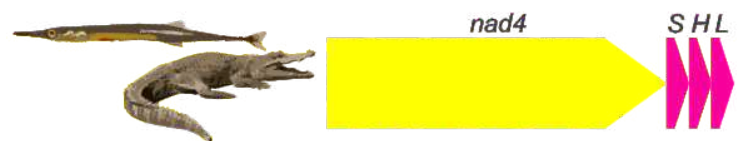

Convergence 8. Actinopteri: Alepocephaliformes (1), Perciformes sedis mutabilis (1)

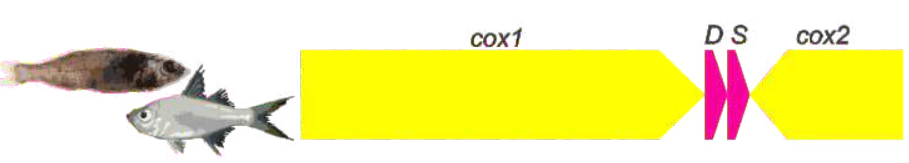

Convergence 9. Actinopteri: Esociformes (1), Tetradontiformes (1)

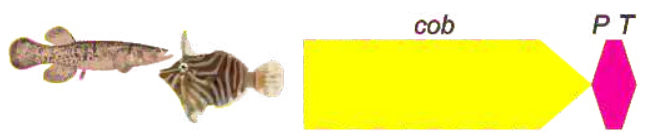

Convergence 10. Actinopteri: Scombriformes (1), Acanthuriformes (1), Lampriformes (1)

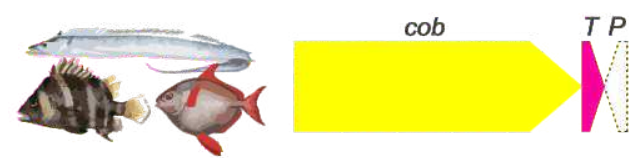

Convergence 11. Actinopteri: Perciformes (1) - Amphibia: Gymnophiona (1)

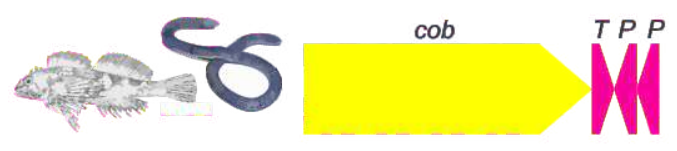


Figures

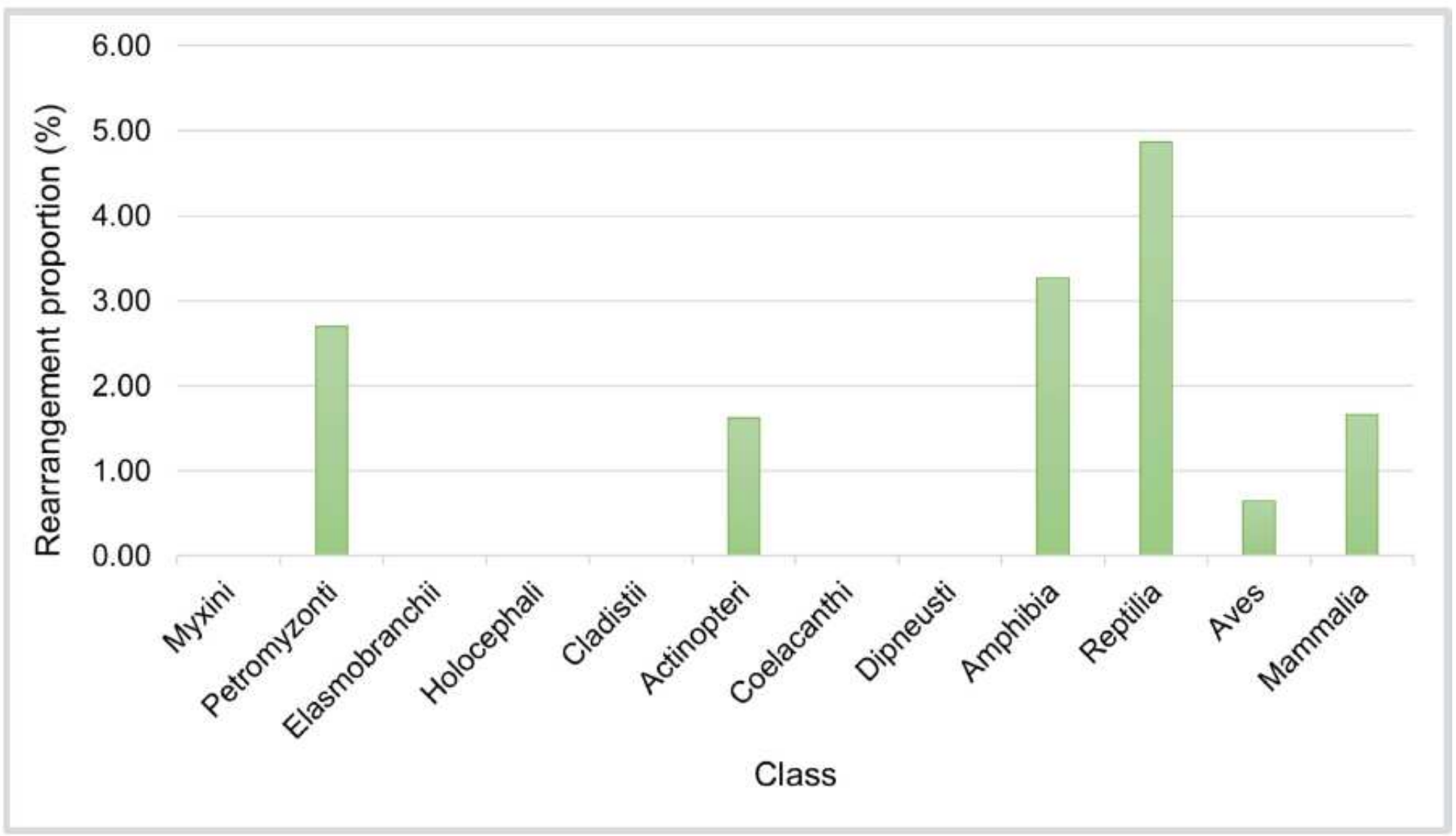

Figure 1

Gene rearrangement proportion values for each of the vertebrate classes sampled. 


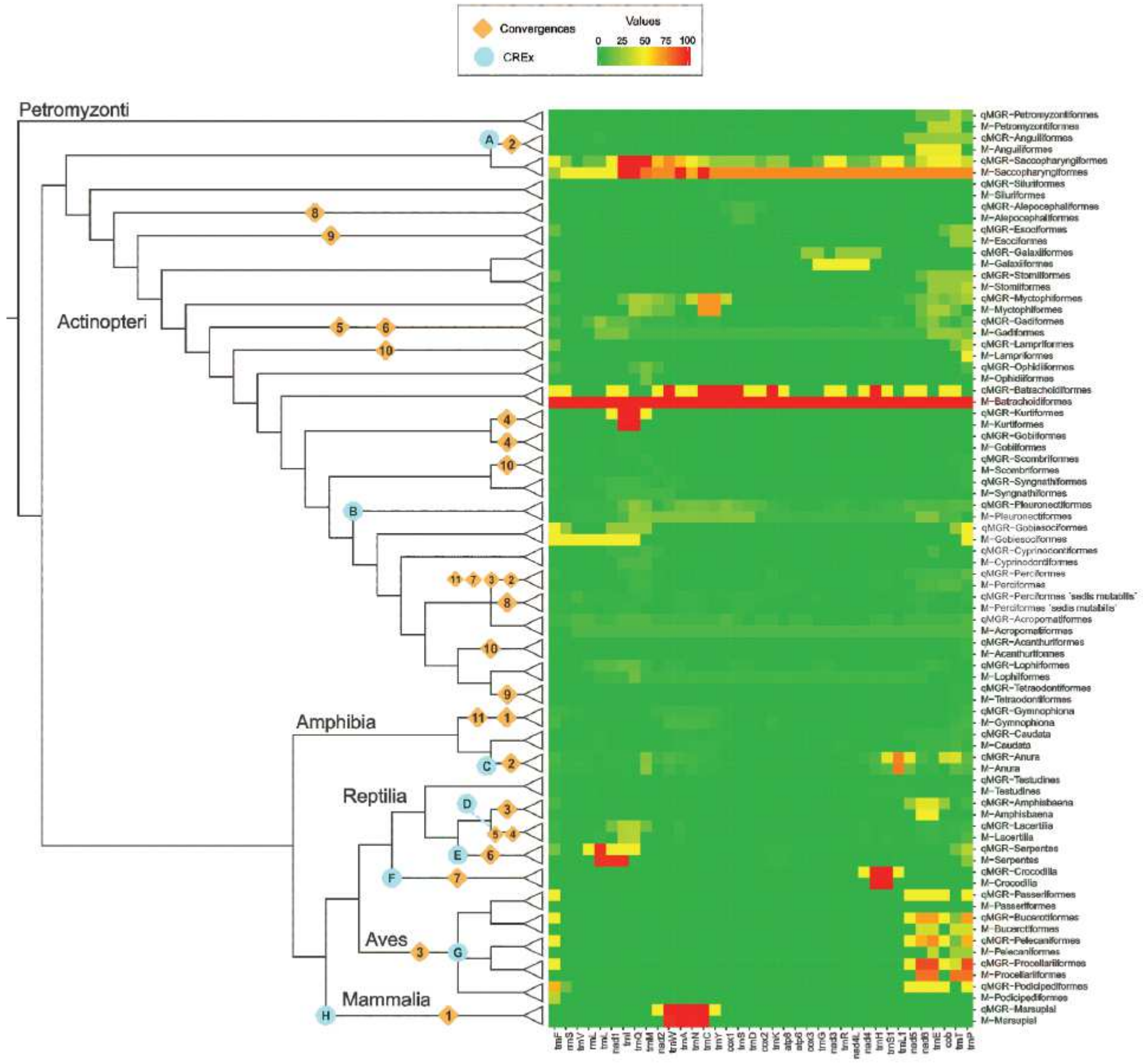

Figure 2

Heat map of gene rearrangement analysis among vertebrate classes. Phylogenetic relationships are as interpreted in 21. Dark green colors show a low proportion of change and red colors show a high number of rearrangement events for each of the individual genes within each taxonomic order that exhibited rearrangements in mitochondrial sequences. Orange diamonds show the number of convergences detected in that taxonomic order; aquamarine blue circles indicate that a CREx representation was performed for that taxonomic order. 


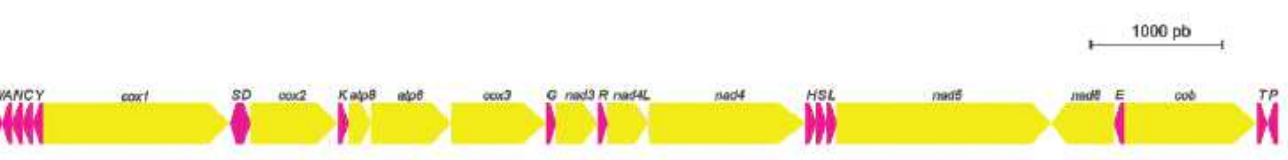

Convergences present in vertebrates. The number of species involved is indicated in parentheses

Convergence 1. Amphibia: Gymnophiona (1) - Mammalia: Marsupialia (29)

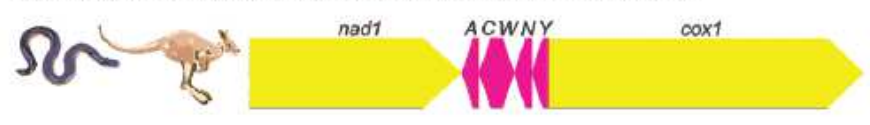

Convergence 2. Actinopteri: Anguilliformes (14), Perciformes (3) - Amphibia: Caudata (2)

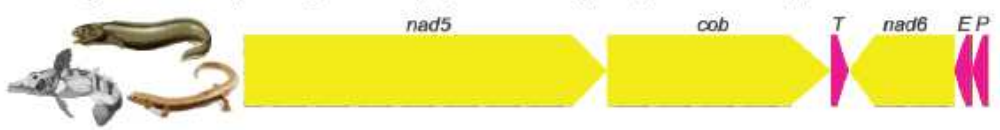

Convergence 3. Actinopteri: Perciformes (1) - Amphibia: Amphisbaenia (1) - Aves (591)

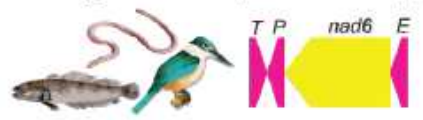

Convergence 4. Actinopteri: Kurtiformes (1), Gobifformes (1) - Reptilia: Lacertilia (29)

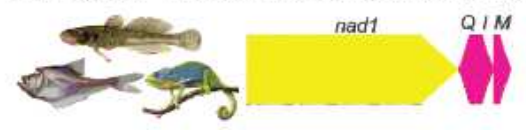

Convergence 5. Actinopteri: Gadiformes (3)-Reptilia: Lacertifia (1)

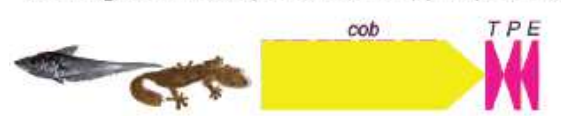

Convergence 7. Actinopteri: Perciformes (1) - Reptilia: Crocodilia (18)

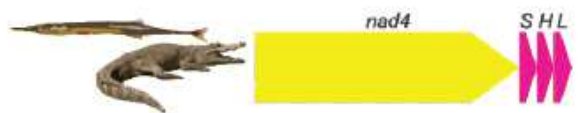

Convergence 8. Actinopteri: Alepocephaliformes (1), Perciformes sedis mutabilis (1)

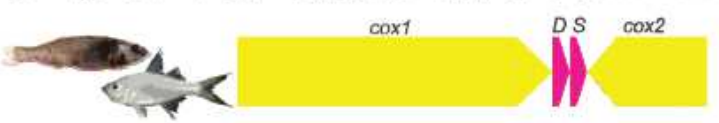

Convergence 9. Actinopteri: Esociformes (1). Tetradontformes (1)

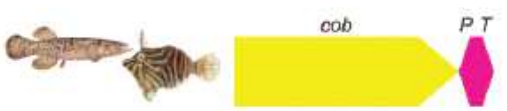

Convergence 10. Actinopteri: Scombriformes (1), Acanthuriformes (1), Lampriformes (1)

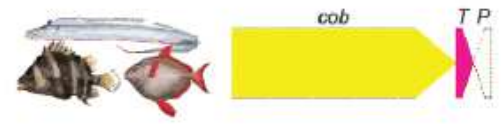

Convergence 11. Actinopteri: Perciformes (1) - Amphibia: Gymnophiona (1)

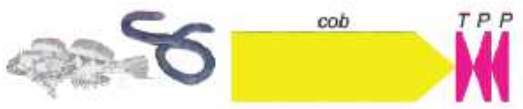

Convergence 6. Actinopteri: Gadiformes (2) - Reptilia: Serpentes (57)

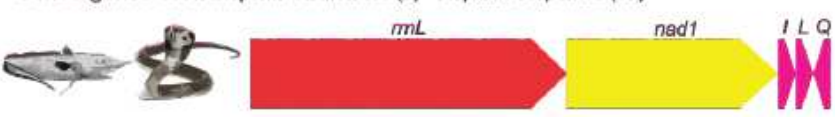

$1000 \mathrm{pt}$

\section{Figure 3}

Evolutionary convergence of mitochondrial gene order rearrangements. This shows only the subset that are rearranged; all other genes share the ancestral arrangement. Arrows show transcriptional orientation. tRNA-encoding genes are labeled with the one-letter code for the corresponding amino acid. In parentheses are the number of species involved in the convergence.

\section{Supplementary Files}

This is a list of supplementary files associated with this preprint. Click to download.

- SupplementaryFigureS1.pdf

- SupplementaryFigureS2.pdf

- SupplementaryTableS1.xlsx 
- SupplementaryTableS2.xIsx 